\title{
SYNTHESIS OF ACETIC ACID FROM ETHANOL BY ELECTROOXIDATION TECHNIQUE USING Ni-Cu-PVC ELECTRODE
}

\author{
Riyanto, Mohamed Rozali Othman, Jumat Salimon \\ Electrosynthesis Laboratory, School of Chemical Sciences and Food Technology, \\ Faculty of Science and Technology, Universiti Kebangsaan Malaysia, \\ 43600 UKM Bangi, Selangor Darul Ehsan, Malaysia
}

Received 14 August 2006

\begin{abstract}
A usage of Ni-Cu-PVC electrode for the oxidation of ethanol by electrochemical technique will be reported in this paper. In this work, the effect of electrodes on the yields of acetic acid was determined. Electrode used was made of the mixtures of $\mathrm{Ni}$ powder, $\mathrm{Cu}$ powder and of polyvinyl chloride (PVC) with various percentages. Electrooxidation of $0.20 \mathrm{M}$ ethanol in 0.16 $\mathrm{M} \mathrm{KOH}(24 \mathrm{~mL})$ were carried out using chrono coulometry (CC) at a potential of $1050 \mathrm{mV}$ for 6 hours with continious stirring. Electrooxdation result obtained was analyzed using High Performance Liquid Chromatography (HPLC). The test result shows that the composition of $\mathrm{Ni}: \mathrm{Cu}: \mathrm{PVC}$ at 75:20:5 have higher efficiency in the electrooxidation of ethanol to acetic acid.
\end{abstract}

Keywords: Ethanol, Electrooxidation, Acetic Acid and Ni-Cu-PVC electrode

\section{INTRODUCTION}

Being as an important industrial chemical, acetic acid was used in the production of polyethylene terephthalate (e.g. for soft drink bottles), cellulose acetate (for photographic film) and vinyl acetate as well as many synthetic fibers and fabrics. Total worldwide production of virgin acetic acid is estimated at $5 \mathrm{Mt} / \mathrm{y}$, approximately half of which is produced in the United States. European production stands at approximately $1 \mathrm{Mt} / \mathrm{a}$ and is declining and $0.7 \mathrm{Mt} / \mathrm{y}$ in Japan. Another 1.5 Mt are recycled each year bringing the total world market to $6.5 \mathrm{Mt} / \mathrm{y}$ [1].

Acetic acid were produced by both synthetically and by bacterial fermentation. Today, the biological route accounts for only about $10 \%$ of world production, but it remains important for vinegar production, as in much of the world food purity laws stipulate that vinegar used in foods must be of biological origin. About $75 \%$ of acetic acid used in chemical industry was made by methanol carbonylation. Process of methanol carbonylation still being used for the production of acetic acid from methanol [1]. Methanol carbonylation process using ordinary chemistry reaction or organic synthesis conventionally. Process of methanol carbonylation needs high cost raw material like methanol, $\mathrm{CO}$ and catalyst. Methanol carbonylation process also need to be carried out high temperature and pressure. This process has many weaknesses, in consequence a production process of acetic acid with electrochemical or more knowledgeable by the name of electrosynthesis technique was proposed.

The present works concern the electrosynthesis of acetic acid from ethanol using electrooxidation technique. Recently, a new electrooxidation of ethanol for application in fuel 
cells system and study of electrochemical oxidation of ethanol were developed [2 - 7]. Those studies may probably lead to the design of catalyst for an effective oxidation of organic molecules that are being used as a low temperature fuel cells. Nevertheless, in spite of an incomplete oxidation, the use of ethanol can be an advantage because such oxidation products can be either acetaldehyde or acetic acid depending on the reaction conditions. These products have a very high commercial interest. Ethanol does not easily evaporate at room temperature, not readily oxidized, non-toxic and easily available from biomass resources $[8,9]$.

The most important part of any electrosynthesis system is the electrode. Usually, however, it is the working electrode that is of greatest concern. The most prudent way to select an electrode, that is, its material and its surface morphology, is, as a general rule, by direct experiment. Besides chemical and electrochemical stability, electrodes are chosen for industrial use have to be relatively inexpensive, highly conducting, and electrocatalytic [10]. Electrooxidation of ethanol with solid electrodes have many weaknesses especially related to the roughness of electrode, wide of contact with condensation and ability of absorption of condensation. In consequence, development of heavily pressed powder electrode require has to be done, which one of its target is to improve the roughness of electrode.

Among other factors that affected the electrooxidation products is the electrode's surface composition (the variability on the particles size either supported and non-supported) and supporting electrolyte. By using $\mathrm{Cu}$ powder with PVC as supported medium, it was expected that particles size can be improve. Usage a nickel mixture with $\mathrm{Cu}$ expected could improve the nature. Nickel has been used as an electrodes by many researches for the electrooxidation of ethanol. Nickel for the oxidation of primary alcohol could yield carboxylic acid [11]. Nickel to form electrode into $\mathrm{Cu}-\mathrm{PVC}$ or has been known as a nanoparticel electrode of. Nickel represent electrocatalytic which is good to yield acetic acid [12].

Nickel can alter acetaldehyde to become acetic acid with the following reaction [12]:

$$
\mathrm{NiO}_{2}+2 \mathrm{CH}_{3} \mathrm{CHO} \longrightarrow \mathrm{Ni}(\mathrm{OH})_{2}+2 \mathrm{CH}_{3} \mathrm{COOH}
$$

Acetaldehyde represents the oxidation product of ethanol at low potential or start of electrolysis which is as follows [13]:

$$
\begin{aligned}
& \text { Ethanol } \longrightarrow \text { acetaldehyde } \longrightarrow \text { acetic acid } \\
& \mathrm{CH}_{3} \mathrm{CH}_{2} \mathrm{OH} \longrightarrow \mathrm{CH}_{3} \mathrm{CHO}+2 \mathrm{H}^{+}+2 \mathrm{e} \quad \mathrm{E}^{0}=0.197 \mathrm{~V}
\end{aligned}
$$

Acetaldehyde later will be converted to become acid acetic.

$$
\mathrm{CH}_{3} \mathrm{CHO}+\mathrm{H}_{2} \mathrm{O} \longrightarrow \mathrm{CH}_{3} \mathrm{COOH}+2 \mathrm{H}^{+}+2 \mathrm{e}^{0} \quad \mathrm{E}^{0}=0.600 \mathrm{~V}
$$

The whole oxidation process that occurred at anode is:

$$
\mathrm{CH}_{3} \mathrm{CH}_{2} \mathrm{OH}+\mathrm{H}_{2} \mathrm{O} \longrightarrow \mathrm{CH}_{3} \mathrm{COOH}+4 \mathrm{H}^{+}+4 \mathrm{e} \quad \mathrm{E}^{0}=0.797 \mathrm{~V}
$$

For the optimization work, the most essential parameter is the selection of an electrode (anode) material, where an anode material should exhibit good electrochemical efficiency, stable in supporting electrolyte used and commercially available. Among these metal, nickel, copper and raney-nickel are highly tested and the cheapest but show low stability because of their high corrosive properties. The weakness of making an electrode with electrodeposition process is $\mathrm{Cu}$ was closed to $\mathrm{Ni}$ so that the nature of electrocatalytic of $\mathrm{Cu}$ will lose. In consequence it is propose that a new electrode design by directly mingling between nickel powder and cupper powder with certain portion, where PVC and tetrahydrofuran (THF) as a solvent were used to strengthen the bonding. This in house design electrode is expected can be exploited the nature of catalytic from both metals nickel of copper. 


\section{EXPERIMENTAL}

\subsection{Solution}

All solutions were prepared by dissolving its analytical grade salt in deionised distilled water. $\mathrm{KOH}$ (R \& M Chemicals) was used as the supporting electrolyte. Nitrogen gas was used to deaerate the solutions for 10 minutes to keep an inert atmosphere over the solution. Ethanol solutions were prepared by dilution of absolute ethanol (BDH laboratory) with deionised water.

\subsection{Preparation of electrodes}

$\mathrm{NiCu}-\mathrm{PVC}$ electrode was made by mixing together Cu powder (100 mesh $99.9 \%$, Systerm), $\mathrm{Ni}$ powder (100 mesh 99.9\%, Aldrich Chemical Company) and PVC at a certain portion, $4 \mathrm{~mL}$ tetrahydrofuran (THF) was later added and swirled. The mixture were later drying in an oven at $50^{\circ} \mathrm{C}$ for 3 hours. Homogenous powder was later pressed at $10 \mathrm{ton} / \mathrm{cm}^{-2}$.

\subsection{Analysis electroxidation product}

Analyses were carried out using the High Performance Liquid Chromatography (HPLC) equipment comprised of a pump (Waters 1515 Isocratic HPLC Pump), a column (C18) and two detectors which are an UV-visible detector (Waters 2487, Duel $\lambda$ Absorbance detector) and a differential refractometer set on line. Chromatograms were recorded and integrated by an integrator-calculator (Merck-Hitachi D-2500). All experiments were carried out at room temperature. The mobile phase of acetonitrile in $0.1 \% \mathrm{H}_{3} \mathrm{PO}_{4}$ was applied.

\subsection{Electrochemical measurements (cyclic voltammetry and chrono coulometry)}

Universal Pulsa Dynamic EIS, Voltammetry, Voltalab potentiostat (Model PGZ 402) was used for electrochemical measurements while data acquisition was accomplished by using the Voltamaster 4 software. Voltammetric experiments were carried out in a three electrodes system using $\mathrm{NiCu}-\mathrm{PVC}$ as a working electrode, an $\mathrm{Ag} / \mathrm{AgCl}(\mathrm{KCl}$ saturated) or SCE as reference electrode and a platinum plat as the counter electrode. All the potentials given are with respect to the SCE reference electrode.

\subsection{Experiment procedure}

The electrolysis process was performed on a solution of $0.25 \mathrm{M}$ ethanol in $1.0 \mathrm{M}$ and $0.1 \mathrm{M}$ $\mathrm{KOH}$ at room temperature. The electrochemical studies by cyclic voltammetry (CV) and oxidation of ethanol by potentiostatic method chrono coulometry (CC) were performed in a glass electrochemical cell (volume $25 \mathrm{~mL}$ ) with a platinum plat as a counter and $\mathrm{NiCu}-\mathrm{PVC}$ as working electrodes. The potential of the working electrodes was measured against a SCE reference electrode. Electrolysis products were analyzed by the High Performance Liquid Chromatography (HPLC).

\section{RESULTS AND DISCUSSION}

\subsection{Physical characterizations of the electrode}

Figure 1a shows that made electrode by including $\mathrm{Cu}$ powder and $\mathrm{Ni}$ powder into $\mathrm{PVC}$ will yield a scraggly surface. Existence of white colours show PVC, black is $\mathrm{Ni}$ metal and red is $\mathrm{Cu}$ metal. This may cause the crudity of the electrode surface. The weaknesses of electrode design like this is the metal concentration on the electrode surface do not uniform, so that its ability 
may reduce.. After using, $\mathrm{NiCu}-\mathrm{PVC}$ electrode will give a green colour on the surface, because $\mathrm{Ni}$ will be oxidized to form $\mathrm{Ni}(\mathrm{OH})_{2}$.

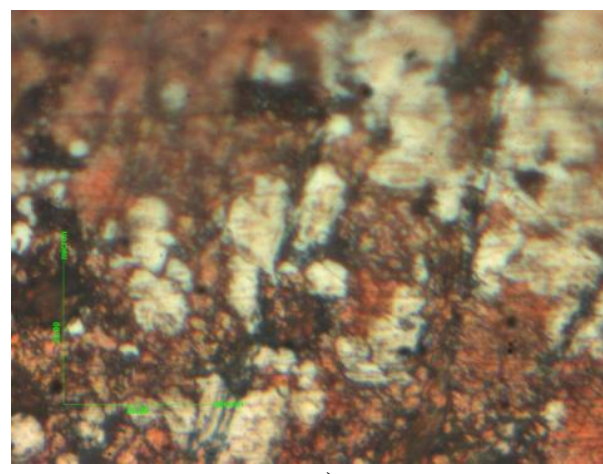

a)

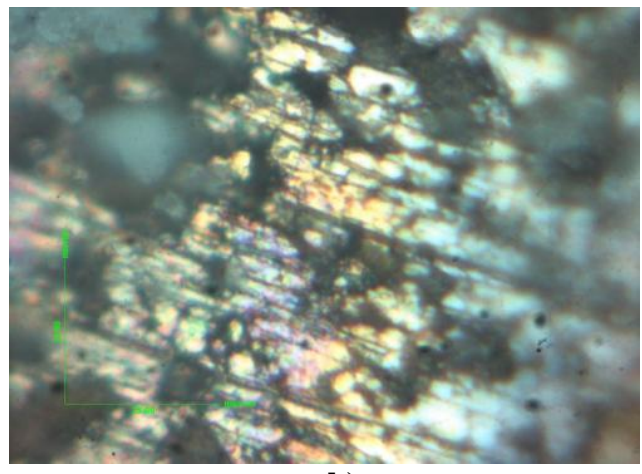

b)

Fig. 1: Image analyser picture of a) $\mathrm{NiCu}-\mathrm{PVC}$ electrode originally and b) $\mathrm{NiCu}-\mathrm{PVC}$ electrode after used.

\subsection{Voltammetric response using cyclic voltammetry}

At Fig. 2. cyclic voltammograms sweep from a potential of $-700 \mathrm{mV}$ to $700 \mathrm{mV}$ and back to the starting potential. A1, A2, A3 and A4 represents the peaks obtained on the anodic scan or anodic peaks. This peaks due to the oxidation $\mathrm{Cu}$. $\mathrm{Cu}$ metal is easy to oxidize to form its oxide compound. In alkaline medium, it will form a thin coating on the surface of the electrode $\mathrm{Cu}_{2} \mathrm{O}$, $\mathrm{CuO}$, and $\mathrm{Cu}(\mathrm{OH})_{2}$, besides other species, are deposited on the electrode surface depending on the potential, $\mathrm{pH}$, the mass-transport conditions and ageing and surface restructuring processes [14].

Peak at $-400 \mathrm{mV}$ (A1 peak), represent the oxidation $\mathrm{Cu}(0)$ or $\mathrm{Cu}$ metal to become $\mathrm{Cu}$ (I) that is in the form of $\mathrm{CuOH}$ and $\mathrm{Cu}_{2} \mathrm{O} . \mathrm{Cu}_{2} \mathrm{O}$ represent the intermediate layer $[15,16]$ :

$$
\begin{aligned}
& \mathrm{Cu}+\mathrm{OH}^{-} \longrightarrow \mathrm{CuOH}+\mathrm{e}^{-} \\
& 2 \mathrm{CuOH} \longleftrightarrow \mathrm{Cu}_{2} \mathrm{O}+\mathrm{H}_{2} \mathrm{O}
\end{aligned}
$$

The biggest and highest peak of $\mathrm{A} 2$ represent the oxidation of $\mathrm{Cu}(0)$ becoming $\mathrm{Cu}$ (II) and $\mathrm{Cu}$ (I) become $\mathrm{Cu}$ (II), with the following reaction:

$$
\begin{aligned}
\mathrm{Cu}(0)+2 \mathrm{OH}^{-} & \longrightarrow \mathrm{Cu}(\mathrm{OH})_{2}+2 \mathrm{e}^{-} \\
\mathrm{Cu}(\mathrm{OH})_{2} & \longleftrightarrow \mathrm{CuO}+\mathrm{H}_{2} \mathrm{O}
\end{aligned}
$$

Reaction of oxidation also come from $\mathrm{Cu}_{2} \mathrm{O}$ represent layer which there are on the surface of electrode.

$$
\begin{aligned}
\mathrm{Cu}_{2} \mathrm{O}+2 \mathrm{OH}^{-}+\mathrm{H}_{2} \mathrm{O} & \longrightarrow 2 \mathrm{Cu}(\mathrm{OH})_{2}+2 \mathrm{e}^{-} \\
\mathrm{Cu}(\mathrm{OH})_{2} & \longleftrightarrow \mathrm{CuO}+\mathrm{H}_{2} \mathrm{O}
\end{aligned}
$$

The anodic peak (A3) which represent the oxidation of $\mathrm{Ni}$ (II) to $\mathrm{Ni}$ (III) happened at maximum potential $320 \mathrm{mV}$ (Fig. 2a). The thin layer of $\mathrm{Ni}(\mathrm{OH})_{2}$ on the surface of nickel electrode reacted with $\mathrm{OH}^{-}$and forming $\mathrm{NiOOH}$ that will adsorbs ethanol on the surface of the electrode. $\mathrm{NiOOH}$ was unctioning as catalyst to form intermediates. $\mathrm{OH}^{-}$species coming from $\mathrm{KOH}$ or water has an important role. In consequence electrolyte concentration $(\mathrm{KOH})$ has an big effect on in the 
electrooxidation of ethanol to acid acetic. Reaction mechanism that occurred on the electrode surface can be seen from formed of spongy on the electrode surface (Fig. 3).

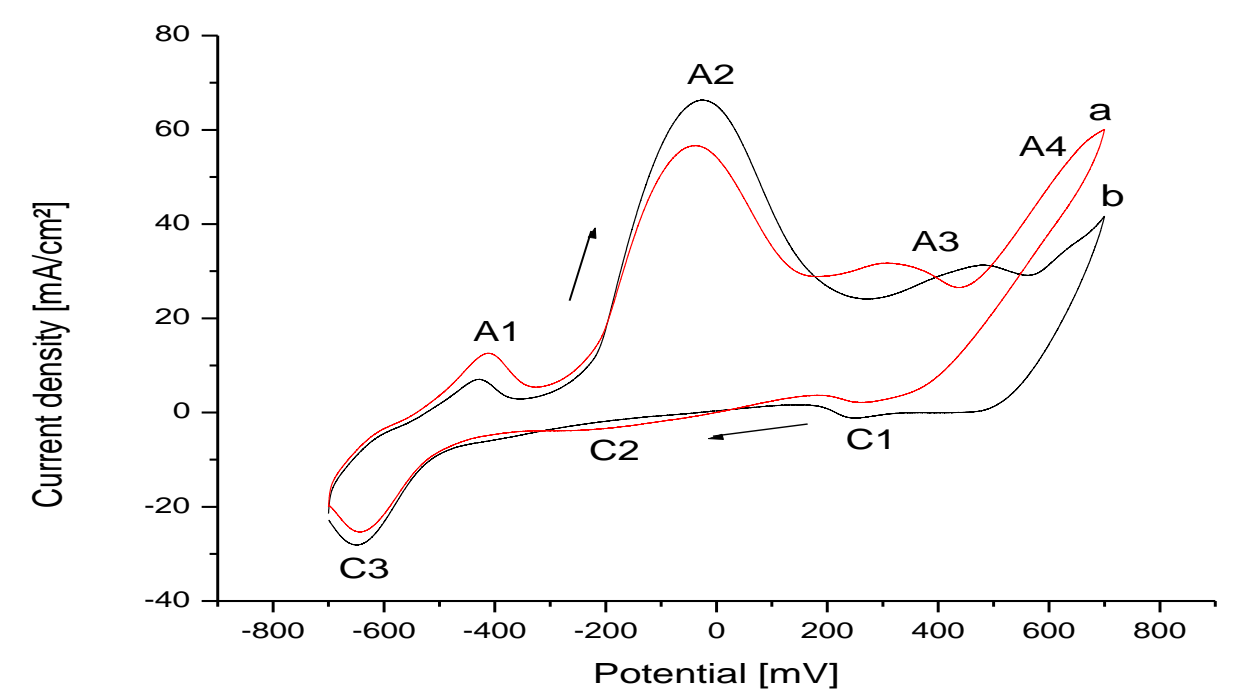

Fig. 2: Cyclic voltammograms of NiCu-PVC electrodes in a) $0.20 \mathrm{M} \mathrm{ethanol}+0.8 \mathrm{M} \mathrm{KOH}$ and b) $0.8 \mathrm{M} \mathrm{KOH}+20 \mathrm{~mL}$ water (without ethanol). Scan rate $10 \mathrm{mV} / \mathrm{Sec}$.

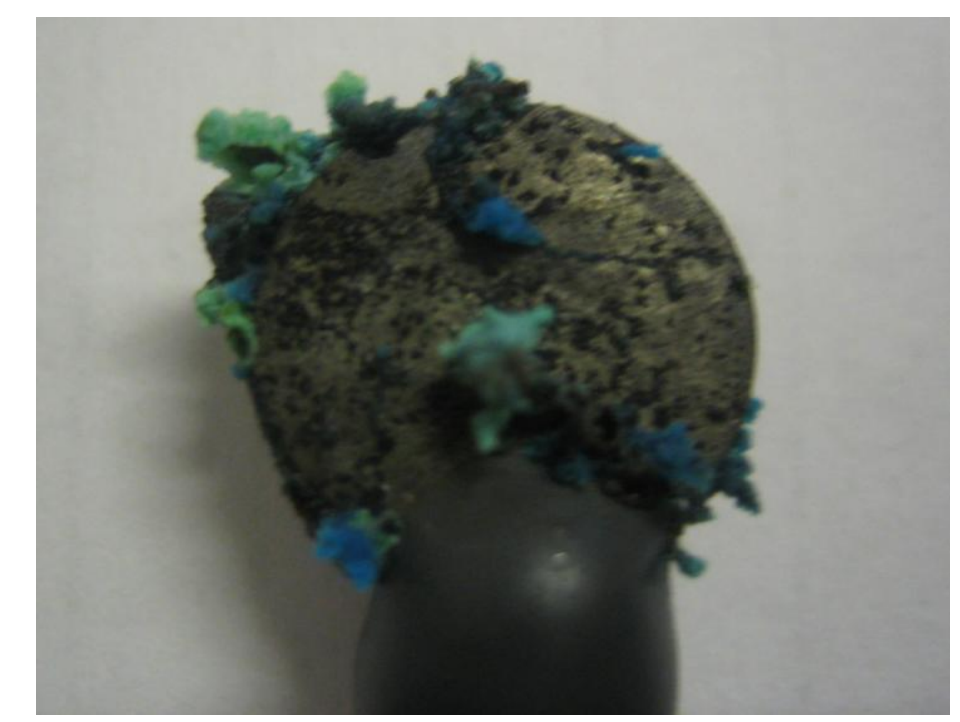

Fig. 3: Spongy at NiCu-PVC electrodes, the electrolysis $E=1050 \mathrm{mV}$ experiments using $0.2 \mathrm{M}$ $\mathrm{C}_{2} \mathrm{H}_{5} \mathrm{OH}, 0.16 \mathrm{M} \mathrm{KOH}$, electrolysis time 6 hours at room temperature.

There are spongy with four different colours black, blue, green and gray (Fig. 3). Black colour may represent of $\mathrm{CuO}$ compound (reaction 8 and 10) and $\mathrm{NiOOH}$, green colour represent $\mathrm{Ni}(\mathrm{OH})_{2}$ and $\mathrm{Cu}_{2} \mathrm{O}_{3}$ compound, blue colour is the $\mathrm{Cu}(\mathrm{OH})_{2}$ compound while gray colour compound not yet been determined. The forming of the compound only observed for electrolysis at high concentration of $\mathrm{KOH}$. With longer electrolysis times more and more spongy will be formed, the compounds are hard and very stable. The peak of A3 which 
represent the oxidation of $\mathrm{Ni}$ (II) to $\mathrm{Ni}$ (III) can be seen by $\mathrm{Cu}-\mathrm{PVC}$ cyclic voltammograms (Fig. 4). At Fig. 4 there is no A3 peak (at $320 \mathrm{mV}$ ), because there are no nickel in the Cu-PVC.

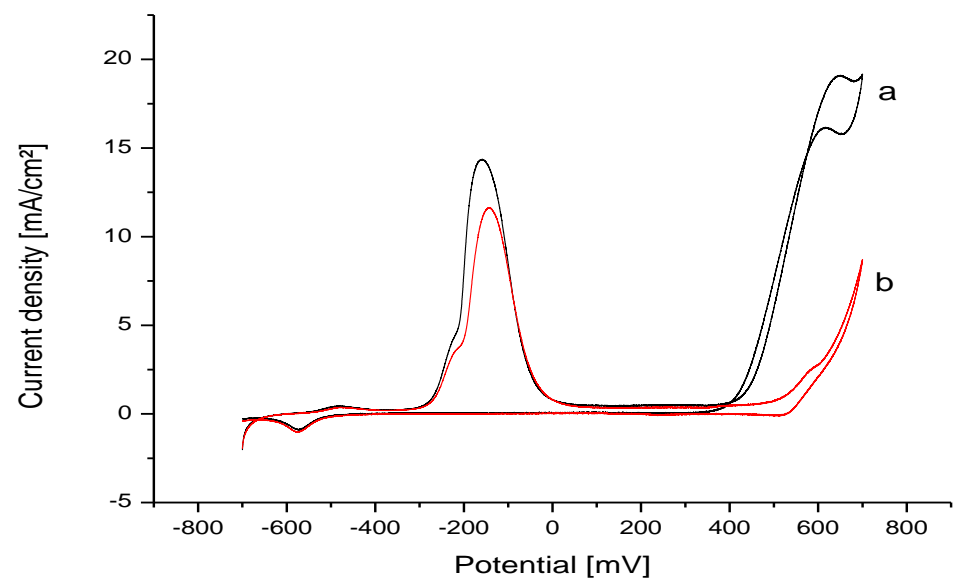

Fig. 4: Cyclic voltammograms of a) $0.2 \mathrm{M}$ ethanol $20 \mathrm{~mL}$ in $0.8 \mathrm{M} \mathrm{KOH}$ and b) in $0.8 \mathrm{M} \mathrm{KOH}$ using $\mathrm{Cu}-\mathrm{PVC}$ electrodes. Scan rate $10 \mathrm{mV} / \mathrm{Sec}$.

Results to identify this were done by Libria and Pereira [12, 17]. Peak of A4 represent furthermore oxidation peak of $\mathrm{Cu}$ become $\mathrm{Cu}$ (III). $\mathrm{Cu}$ (III) species are more easily to be formed, and indeed detected at high hydroxide concentration by the reaction below [15]:

$$
\begin{aligned}
\mathrm{Cu}(0)+3 \mathrm{OH}^{-} & \longrightarrow \mathrm{HCuO}_{2}^{-}+\mathrm{H}_{2} \mathrm{O}+2 \mathrm{e}^{-} \\
\mathrm{Cu}(\mathrm{OH})_{2}+2 \mathrm{OH}^{-} & \longleftrightarrow \mathrm{CuO}_{2}^{-}+2 \mathrm{H}_{2} \mathrm{O} \\
2 \mathrm{CuO}+2 \mathrm{OH}^{-} & \longleftrightarrow \mathrm{Cu}_{2} \mathrm{O}_{3}+\mathrm{H}_{2} \mathrm{O}+\mathrm{e}^{-}
\end{aligned}
$$

$\mathrm{Cu}$ (III) was detected at a potential $0.6 \mathrm{~V}$ during the positive scan. The formation of $\mathrm{Cu}$ (III) species at $\mathrm{E}>0.6 \mathrm{~V}$ may have a similar role in the electro catalytic process. Mechanism of electro catalytic that happened at ethanol electro oxidation is [12]:

$$
\begin{aligned}
\mathrm{CuO}+\mathrm{OH}_{(\mathrm{ads})}^{-} & \rightleftharpoons \mathrm{CuOOH}^{\cdot}+\mathrm{e}^{-} \\
\mathrm{CuOOH}+\mathrm{CH}_{3} \mathrm{CH}_{2} \mathrm{OH}_{(\mathrm{ads})} & \rightleftharpoons \mathrm{CuO}+\left[\mathrm{C}_{2} \mathrm{H}_{4} \mathrm{OH}\right]^{\cdot}+\mathrm{H}_{2} \mathrm{O} \\
{\left[\mathrm{C}_{2} \mathrm{H}_{4} \mathrm{OH}\right]^{\cdot} } & \rightleftharpoons \text { products of ethanol degradation }
\end{aligned}
$$

Electrode designed in this study was different compared to by Periera et al. ${ }^{12}$. In this study, both metal, $\mathrm{Ni}$ and $\mathrm{Cu}$ able to share as an electrocatalytic. During the electrolysis, electrode surface will form $\mathrm{NiOOH}, \mathrm{CuO}$ and $\mathrm{Cu}_{2} \mathrm{O}$ compounds which were able to act as a catalyst so the weakness of electrode designed by Periera et al. ${ }^{12}$ could be overcome. In the electrode designed by Periera et al. ${ }^{12}$, $\mathrm{Ni}$ will be deposited on $\mathrm{Cu}$ during the process of electrodeposition, so $\mathrm{Cu}$ surface will be not contacted with reactant resulting that $\mathrm{Cu}$ cannot act as an electrocatalyst.

$\mathrm{C} 1, \mathrm{C} 2$ and $\mathrm{C} 3$ peaks represent cathode peaks which is scan from $700 \mathrm{mV}$ to $-700 \mathrm{mV}$. C1 peak represents reduction of $\mathrm{Ni}$ (III) to $\mathrm{Ni}$ (II) at potential of $250 \mathrm{mV}$. C2 peak represents reduction of $\mathrm{Cu}$ (III) to $\mathrm{Cu}$ (II) and of $\mathrm{C} 3$ at potential $-650 \mathrm{mV}$ represent reduction peak of $\mathrm{Cu}$ (II) to $\mathrm{Cu}$ (I) and $\mathrm{Cu}(\mathrm{I})$ to $\mathrm{Cu}(0)$. 


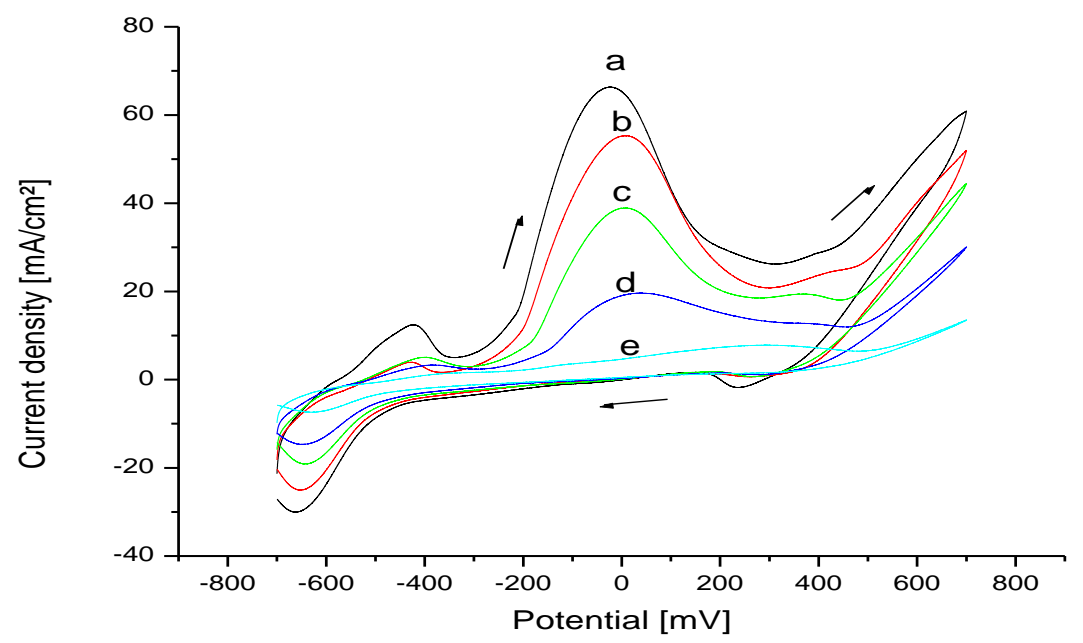

Fig. 5: Cyclic voltammograms of $\mathrm{NiCu}-\mathrm{PVC}$ electrodes in $0.20 \mathrm{M}$ ethanol $+\mathrm{KOH}:$ a) $0.8 \mathrm{M} \mathrm{b}$ ) $0.6 \mathrm{Mc}$ ) $0.4 \mathrm{Md}$ ) $0.2 \mathrm{M}$ and e) $0.1 \mathrm{M}$. Scan rate $10 \mathrm{mV} / \mathrm{Sec}$.

At Fig. 5, greater concentration of $\mathrm{KOH}$ hence increase the current density, good to peak at 0 $\mathrm{mV}$ (peak A2 at Fig. 2) and also peak at $600 \mathrm{mV}$. Invisible peak progressively at concentration of $\mathrm{KOH}$ under $0.5 \mathrm{M}$, no current peaks were observed in the positive potential range when cyclic voltammograms were recorded with the copper electrodes at supporting electrolyte concentrations lower than $0.1 \mathrm{M} \mathrm{NaOH} \mathrm{[14].} \mathrm{The} \mathrm{rate} \mathrm{of} \mathrm{an} \mathrm{electrochemical} \mathrm{process} \mathrm{is}$ expressed by the current density that is the current flow per unit area. Lower current density would signify very low rates of conversion of reactant.

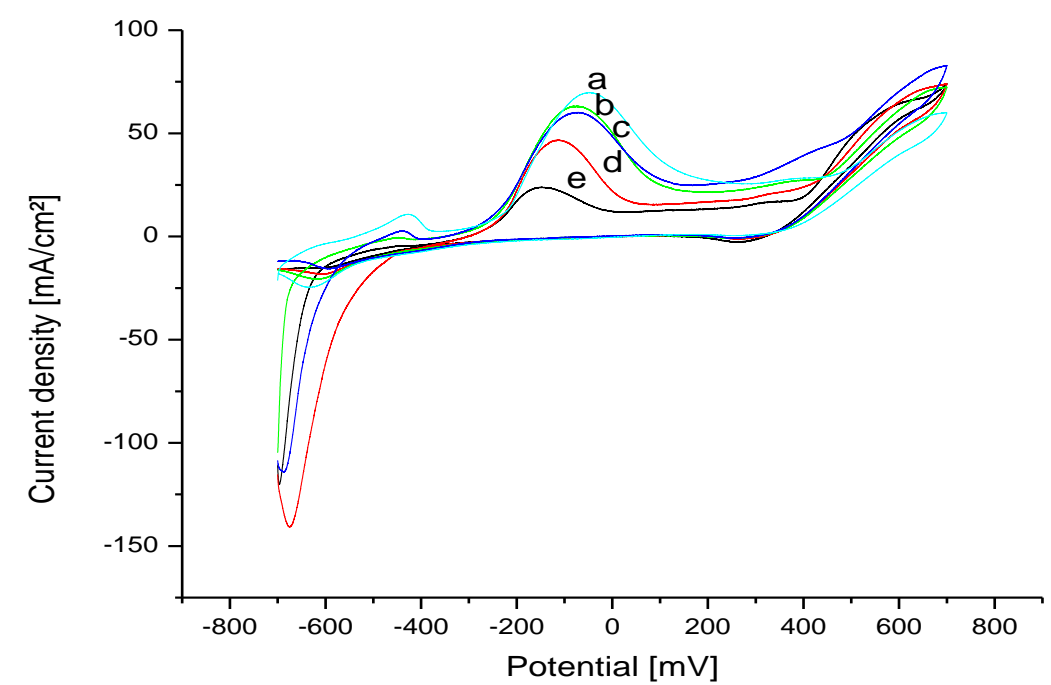

Fig. 6: Cyclic voltammograms in 0.20 M ethanol $+0.16 \mathrm{M} \mathrm{KOH} \mathrm{using} \mathrm{NiCu-PVC} \mathrm{electrodes}$ by various comparison Ni:Cu:PVC is; a) 45:50:5 b) 55:40:5 c) 65:30:5 d) 75:20:5 and e) $85: 10: 5$.

Figure 6 shows that are greater concentration of nickel, current density decreased, conversely concentration of copper current density increased. Both of this metal is expected to give the nature of catalytic which is better compared to $\mathrm{Cu}-\mathrm{PVC}$ and $\mathrm{Ni}-\mathrm{PVC}$ electrode. If the 
composition of $\mathrm{Cu}$ is lower in the electrode, hence lower peak height. Meanwhile Ni peak also experience of degradation but did not as much as $\mathrm{Cu}$. At higher $\mathrm{KOH}$ concentration, $\mathrm{Cu}$ will be more easily to oxidize compared with $\mathrm{Ni}$.

\subsection{Analysis of electrooxidation products}

Table 1: Reaction yields of acetic acid obtained by the HPLC analysis of the electrolysis $E=$ $1050 \mathrm{mV}$ experiments using $0.20 \mathrm{M} \mathrm{C}_{2} \mathrm{H}_{5} \mathrm{OH}, 0.16 \mathrm{M} \mathrm{KOH}$, electrolysis time 6 hours at room temperature. Electrode surface area $1.0 \mathrm{~cm}^{2}$

\begin{tabular}{cccc}
\hline $\begin{array}{c}\text { Type Electrodes } \\
\text { (Anode) }\end{array}$ & $\begin{array}{c}\text { Conversion to } \\
\text { Acetic acid (\%) }\end{array}$ & $\begin{array}{c}\text { Current Density } \\
\left(\mathbf{m A} / \mathbf{c m}^{\mathbf{2}}\right)\end{array}$ & $\begin{array}{c}\text { Current } \\
\text { Efficiency (\%) }\end{array}$ \\
\hline NiCu-PVC (45:50:5) & 16 & 16.79 & 41.36 \\
NiCu-PVC (55:40:5) & 20 & 20.91 & 49.44 \\
NiCu-PVC (65:30:5) & 29 & 30.87 & 93.54 \\
NiCu-PVC (75:20:5) & 39 & 41.47 & 95.33 \\
\hline
\end{tabular}

Table 1 shows that the electrolysis of $0.20 \mathrm{M}$ ethanol in $0.16 \mathrm{M} \mathrm{KOH}$ electrolyte give of better result if electrode with higher composition of nickel was used, due to higher concentration electrolyte were very good to nickel. At higher supporting electrolyte concentration $(0.16 \mathrm{M}$ $\mathrm{KOH}) \mathrm{Cu}$ will be easily oxidized to forms $\mathrm{Cu}^{2+}$ (at anode) while at cathode (Pt electrode), $\mathrm{Cu}^{2+}$ will be reduced back to $\mathrm{Cu}$. This event can be seen from the deposition of $\mathrm{Cu}$ on the cathode surface hence a smaller current density and of current efficiency were recorded (Table 1). At higher composition of $\mathrm{Cu}$, cathode $(\mathrm{Pt})$ will stop functioning for electrolysis especially with higher electrolysis time due to electrodeposition of $\mathrm{Cu}$ on Pt electrode (cathode) surface

\section{CONCLUSION}

$\mathrm{NiCu}-\mathrm{PVC}$ electrode has good ability to oxidize ethanol to acid acetic. Ability of NiCu-PVC electrode were determined by comparison of both of nickel and copper metal. NiCu-PVC electrode with the higher composition of nickel will give a better results compare to $\mathrm{Cu}$.

\section{REFERENCES}

1. Weinberg, N.L. (2002), Industrial organic electrosynthesis with some advice on approaches to scaleup, Electrochemistry encyclopedia, New York.

2. Camara, G.A., de Lima, R.B., and Iwasita, T. (2004), Catalysis of ethanol electrooxidation by PtRu: the influence of catalysts composition, Electrochemistry Communications, 6, pp. 812-815.

3. Tripkovic, A.V., Popovic, K.D., and Lovic, J.D. (2001), The influence of the oxygen containing species on the electrooxidation of the $\mathrm{C} 1-\mathrm{C} 4$ alcohols at some platinum single crystal surfaces in alkaline solution, Electrochim. Acta, 46, pp. 3163-3173.

4. Schmidt, V.M. and Iannielo, R. (1996), Electrochemical reactivity of ethanol on porous Pt and PtRu: Oxidation/reduction reaction in $1 \mathrm{M} \mathrm{HClO4,} \mathrm{J.} \mathrm{Phys.Chem.} \mathrm{100,} \mathrm{pp.} \mathrm{17901-}$ 17908.

5. Iwasita, I. Dalbeck, R. Pastor, E., and Xia, X. (1993), Progress in the study of electrocatalytic reaction of organic species, Electrochemica Acta, 39, pp. 1817-1823. 
6. Chang, S.C, Leung, L.W.H., and Weaver, M.J. (1990), Metal crystallinity effects in electrocatalysis as probed by real time FTIR spectroscopy: Electrooxidation of formic acid, methanol and ethanol on ordered low index platinum surfaces, J. Phys. Chem., 94, pp. 6013-6021.

7. Tarasevich, M.R, Karichev, Z.R., Bogdanovskaya, V.A, Lubnin, E.N., and Kapustin, A.V. (2005), Kinetics of ethanol electrooxidation at RuNi catalysts, Electrochemistry Communications, 7, pp. 141-146.

8. Liao, S., Linkov, V., and Petric, L. (2004), Anodic oxidation of ethanol on inorganic membrane alkalined electrodes, Applied Catalysis, 258, pp. 183-188.

9. Lamy, C., Rousseau, S., Belgsir, E.M., Countanceau, J.M., and Leger (2004), Recent progress in the direct ethanol fuel cell development of new platinum-tin electrocatalysts, Electrochim. Acta, 49, pp. 3901-3908.

10. Weinberg, N.L. (1983), Electrosynthesis Technology, J. Chem. Edu., 60, pp. 268-270.

11. Kaulen, J. and Schafer, H.J. (1982), Oxidation of alcohol by electrochemically regenerated nickel oxide hydroxide selective oxidation of hydroxysteroids, Electrochim. Acta, 38, pp. 3299-3308.

12. Pereira, M.G. Jimenez, M.D. Elizalde, M.P. Robledo, A.M., and Vante, N.A. (2004), Study of the electrooxidation of ethanol on hydrophobic electrodes by DEMS and HPLC, Electrochim. Acta, 49, pp. 3917-3925.

13. Hitmi, H., Belgsir, E.M., Leger, J.M., Lamy, C. \& Lezna, R.O., A kinetik analysis of the electrooxidation of ethanol at a platinum electrode in acid medium, (1994), Electrochim. Acta, 39: 407-415.

14. Paixao, T.R.L.C., Corbo, D., and Bertotti, M. (2002), Amperometric determination of ethanol in beverages at copper electrodes in alkaline medium, Anal. Chim. Acta, 472, pp. 123-131.

15. Marioli, J.M and Kuwana, T. (1992), Electrochemical characterization of carbohydrate oxidation at copper electrodes. Electrochim. Acta, 37, pp. 1187-1197.

16. Brisard, G.M., Rudnicki, J.D., McLarnon, F., and Cairns, E.J. (1995), Aplication of probe beam deflection to study the electrooxidation of copper in alkaline media. Electrochim. Acta, 40, pp. 859-865.

17. Kibria, A.K.M. and Taradfar, S.A. (2002), Electrochemical studies of nickel-copper electrode for the oxygen evolution reaction (EOR), Int J Hydrogen Energy, 27, pp. 879-884. 